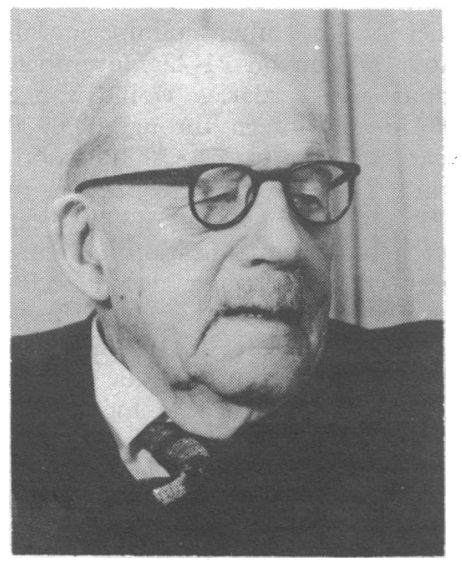

Sir Rickard Christophers, F.R.S., celebrated his hundredth birthday on 27 November (see leading article at p. 506).

\section{Maternal and Child Welfare}

As part of the celebration of its diamond jubilee, the National Association for Maternal and Child Welfare held a reception at Goldsmith's Hall, London, on 28 November, at which the Queen was present. The Queen is patron of the association, whose objectives are the furtherance of education in all aspects of maternity and child welfare through its conferences and meetings, research promotion, and publication of books and journals.

\section{Royal Free Hospital}

The Royal Free Hospital and School of Medicine held a dinner at the Savoy Hotel after the Marsden lecture on 22 November (see p. 561), with Mr. George Qvist in the chair. Lord Thomson of Fleet proposed the health of the hospital and school and Mrs. Stephanie Robinson replied. The guests were toasted by Dr. Euan Campbell and the Mayor of Camden, Councillor R. Collins, replied. Miss Kathleen Robinson proposed the health of the chairman.

\section{COMING EVENTS} Royal College of Physicians of London.--
Teach-in, "Medical Genetics for the M.R.C.P. (U.K.)," 4 December. For details see advertisement on page ix.

British Thoracic and Tuberculosis Association.-Meeting, 10 December, 2 p.m., Royal College of Physicians of London. Details and application forms from the administrative secretary, B.T.T.A., 59. Portland Place, London W1N 3AJ. (Tel. 01-636 3810.)

Royal Society of Medicine.-Holiday lectures suitable for young people between the ages of 14 and 19, on 31 December, 2, 4 January, 2.30 p.m. Details and tickets (free) are obtainable from the information officer, R.S.M., 1 Wimpole Street, London W1M 8AE. (Tel. 01-580 2070.)

Exercise in Health and Disease.-International conference, Wellington, New Zealand, 4-8 February, 1974. Details from The Secretary, Wellington Postgraduate Medical Society (Inc), Wellington Hospital, Wellington, New Zealand.

Royal College of Physicians of London.Conference, "Radiology for Physicians," 28-29 March. For details see advertisement on page ix.
Centre for Postgraduate Psychiatry, Birmingham.-Details of the programme of lectures and open postgraduate meetings, January-May, are obtainable from the secretary, Charles Burns and Uffculme Clinics, Queensbridge Road, Moseley, Birmingham B13 8QD. (Tel. 021-499 4011.)

Northwick Park Hospital and Clinical Research Centre.-Copies and details of the postgraduate diary, January-June, including seminars, study days and evening meetings, are obtainable from the clinical tutor's office, Northwick Park Hospital, Watford Road, Harrow, Middx, HA1 2UJ. (Tel. 01-864 5311, extn. 2210.)

\section{SOCIETIES AND LECTURES} For attending lectures marked a fee is charged
or a ticket is required. Applications should be
made first to the institution concerned.

Monday, 3 December

INSTITUTB OF DBRMatology. -4.30 p.m., Dr. A. Jarrett: Keratin Formation.

INSTITUTE OF LARYNGOLOGY AND OTOLOGY.-5.30 p.m., Clinicopathological conference.
RoYAL COLLEG OF SURGBONS OP ENGLAND.-4.30 p.m., Erasmus Wilson demonstration by Dr. Diseases.

\section{Tuesday, 4 December}

INSTITUTB of Dermatology. -4.30 p.m., Dr. Y. M. Clayton: Role of Fungi in Skin Disease.

BSTMinster Medical SchoOL.-At Page Street lecture theatre, 5.15 p.m., Pfizer lecture
fessor L. Blumgart: The Ruptured Liver.

\section{Wednesday, 5 December}

OXFORD UNIVERSITY - At Radcliffe Infirmary, 5 p.m., Professor R. J. Lukes (Southern California): Lymphomas.

Pharmaceutical Socibty of Great Britain.-At 17 Bloomsbury Square, London W.C.1, 7 p.m. Harrison memorial lecture by Dr. T. D. Whittet Some Contributions of Pharmacists to Analysis.

TT. MARY'S HOSPITAL, LONDON w.2. -7 p.m., Dr. D. T. Gilchrist: Burns and the Anaesthetist.

W HITTINGTON HOSPITAL, LONDON.-11.30 a.m., Mr. of Investigating and Treating Suspected Venous Thrombosis.

\section{Thursday, 6 December}

Aberdenen Untyersiry.-5 p.m., Professor C. D. Marsden: The Levodopa Story of Parkinson's INSTITUTB OP LARYNGOLOGY AND OTOLOGY.-At Royal College of Surgeons of England, 5.30 p.m., Cortex.

Queen Square, London $W . C .1,6$ p.m., Dr. J. D.
Quition Queen Square, London W.C.1, 6 p.m., Dr. J. D. in the Caloric Test.

RoYal Collage OF PHYsicians of LONDON.-4 p.m., Fitzpatrick lecture by Major-General R. G. Morrison: Dr. Messenger Monsey (1693-1788)country doctor and noted eccentric-Physician to the Royal Hospital, Chelsea (1742-1788).

ROYAL COLLBGB OF SURGBONS OF ENGLAND. -5.30 p.m.; Otolaryngology lecture by Dr. I. C. Whit-

ST. JOSBPH's HOSPICE, LONDON.-At Mare Street, Lamerton: 8 p.m., film and debate by Dr. R. Lamerton: The Atmosphere of a Terminal Unit.
ST. MARY's HOSPITAL MBDICAI SCHOOL.-5.15 p.m., Mr. C. N. Hudson: Intestinal Disorders during Pregnancy.

\section{Friday, 7 December}

Royal Postgraduate Mrdical School.-11 a.m., surgery lecture by Mr. J. C. Smith.

\section{UNIVERSITIES AND COLLEGES}

ROYAL COLLEGE OF SURGEONS IN
IRELAND

F.R.C.S.I.-W. Boustany, F. Brady, J. Colville, J. B. Healy, D. K. Gupta, M. E. A. Hamadien, Mooneeram, C. N. Pidgeon, w. R. Quinlan, P. L. Vaidya, Peng Chee Wong.

\section{ROYAL COLLEGE OF GENERAL}

At the 21st annual general meeting, held on 20 November, attended by the president, the Duke of
Edinburgh, Lady Wolfson, Sir George Godber,
Professor A. Smith and Professor H. V. Warren were appointed Honorary Fellows of the college. The George Abercrombie
Dr. W. A. R. Thomson.

The Fraser Rose gold medal was presented to Dr. A. W. Prince.

Fello following members were elected to the Fellowship: Fraser, R. M. Griffiths, Sheila M. Griffiths, W. J. A Hall-Turner, L. J. Higgins, B. Holden, A. B. H. J. A. MacDonald, B. W. M. Lawrence, G. Lloyd, H. Rosenberg, B. R. Sreenivasan, J. C. Turner, G. Watt, A. E. Wood, P. C. McKinlay, J. P. Musgrove,
T. M. O'Brien, W. J. Treadwell, B. H. Young. Upjohn travelling fellowships were awarded to the following :

W. M.E. Anderson, M. E. Barker, J. A. Clappen, W. A. Frodsham, I. D. Gordon, W. L. Halley, Mathers, K. A. Mourin, R. H. Stephenson, G. M. T. Tate, R. A. Yorke.

The Banting and Best silver medal was presented to Dr. G. W. Thorpe.

The Duke of Edinburgh invested Professor P. S. Byrne as president of the college for 1973-4 and the Duke was subsequently installed as Patron of the

The following officers were elected for 1973-4: Chairman, Dr. J. A. R. Lawson; vice-chairman, Dr. J. P. Horder; deputy vice-chairman, Dr. A. E.
Elliott; honorary treasurer, Dr. S. I. Carne; honorary
scretary, Dr. D. H. Irvine.

\section{APPOINTMENTS}

North-east Metropolitan Regional Hospital BOARD.-Dr. R. A. Durance (consultant in rheumatology and rehabilitation, Colchester and District group); Dr. G. McEnery (consultant paediatrician, Forest group); Dr. A. B. S. Mitchell (consultant in Peneral medine, ansecthetist, Southend group); Dr. B. I. Sacks, Dr. S. A. Visram (consultant psychiatrists, Newham (consultant obstetrician and gynaecologist, Romford group).

\section{Corrections}

\section{Evolution of Bone Disease}

In the article "Evolution of Bone Disease over 10 Years in 135 Patients with Terminal Renal Failure" by G. L. V. Tatler et al. (10 November, p. 315) the third line of the paragraph headed Dialysis Fluid Composition should have read ".... from 2.5 to $3.75 \mathrm{mEq} /$ litre." Also in Table II $\mathrm{mmol} / \mathrm{l}$. should be read as $\mathrm{mEq} /$ litre. The last sentence in this paragraph should have read "... magnesium 1.00 mEql/1."

Female Sterility Produced by Investigation

We regret that owing to a printing error in the letter from Mr. J. C. O'Sullivan (24 November, p. 490) the dilution of methylene blue was wrongly given as $1 \mathrm{ml}$ in $1,000 \mathrm{ml}$ of sterile saline, instead of $1 \mathrm{ml}$ in $100 \mathrm{ml}$.

\section{Notice to Authors}

When original articles and letters for publication are not submitted exclusively to the British Medical fournal this must be stated. Accepted articles may subsequently be selected for publication in the North American monthly edition. Correspondence on editorial business should be addressed to the Editor, British Medical fournal, B.M.A. House, Tavistock Square, London WC1H 9JR. Telephone: 01-387 4499. Telerams: Aitiology, London, W.C.1.

Authors wanting reprints of their articles should notify the Publishing Manager, B.M.A. House, Tavistock Square, WC1H 9JR, on receipt of proofs.

\section{C) British Medical Journal 1973}

All Rights Reserved. No part of this publication may be reproduced, stored in a retrieval system, or transmitted, in any form or by any means, electronic, mechanical, photocopying, recording or otherwise, without the prior permission of the British Medical fournal. 